\title{
Physiological quality of sesame seeds during storage ${ }^{1}$
}

\author{
Qualidade fisiológica das sementes de gergelim durante o armazenamento
}

\author{
Denise de Castro Lima ${ }^{2 *}$, Alek Sandro Dutra ${ }^{3}$ e Juliana de Mesquita Camilo ${ }^{4}$
}

\begin{abstract}
Sesame (Sesamum indicum L.) is one of the oldest oilseed plants used by man, and has great economic potential due to the possibilities for its exploitation in both the domestic and international markets. The objective of this work was to monitor the viability of sesame seeds stored in different environments and packaging, with a view to their conservation. The seeds were packed into paper bags, multiwall paper, black polyethylene and PETE bottles, and stored for a period of 12 months in different environments: dry cold room $\left(10{ }^{\circ} \mathrm{C}\right.$ and $\left.55 \% \mathrm{RH}\right)$, natural environment $\left(30-32{ }^{\circ} \mathrm{C}\right.$ and $\left.75 \% \mathrm{RH}\right)$, refrigerator $\left(4^{\circ} \mathrm{C}\right.$ and $\left.38-43 \% \mathrm{RH}\right)$ and freezer $\left(-20{ }^{\circ} \mathrm{C}\right)$. Every three months the water content of the seeds was determined and germination, accelerated ageing, speed of emergence index, and seedling dry weight were evaluated. The experimental design employed was completely randomised, in a scheme of split-lots, with four replications. The results showed that sesame seeds remain viable for up to twelve months when stored in a dry cold room or refrigerator, regardless of the type of packaging used. In a natural environment, the seeds remain viable for up to six months in storage. Paper packaging is the most suitable for sesame seeds stored in a freezer for up to twelve months.
\end{abstract}

Key words: Storage. Germination. Conservation.

RESUMO - O gergelim (Sesamum indicum L.), é uma das plantas oleaginosas mais antigas e utilizadas pela humanidade, apresenta grande potencial econômico, devido às possibilidades de exploração tanto no mercado nacional como internacional. Objetivou-se com este trabalho monitorar a viabilidade das sementes de gergelim armazenadas em diferentes ambientes e embalagens visando a sua conservação. As sementes foram acondicionadas em embalagens de saco papel, papel multifoliado, polietileno preto e garrafa pet e armazenadas por um período de doze meses em diferentes ambientes: câmara fria e seca $\left(10{ }^{\circ} \mathrm{C}\right.$ e $55 \%$ UR), ambiente natural $\left(30-32{ }^{\circ} \mathrm{C}\right.$ e $75 \%$ UR), geladeira $\left(4{ }^{\circ} \mathrm{C}\right.$ e 38 a $43 \%$ UR $)$ e freezer $\left(-20{ }^{\circ} \mathrm{C}\right)$. A cada três meses as sementes foram submetidas às seguintes avaliações: determinação do teor de água, germinação, envelhecimento acelerado, índice de velocidade de emergência e massa da matéria seca das plântulas. O delineamento experimental utilizado foi o inteiramente casualizado, no esquema de parcelas subsubdivididas, com quatro repetições. Os resultados evidenciaram que as sementes de gergelim permanecem viáveis por até doze meses quando armazenadas em ambiente da câmara fria e seca e da geladeira, independente do tipo de embalagem utilizada. Em ambiente natural, as sementes permanecem viáveis por ate seis meses de armazenamento. Em ambiente do freezer, a embalagem de papel é a mais indicada para o acondicionamento das sementes de gergelim por até doze meses.

Palavras-chave: Armazenamento. Germinação. Conservação.

\footnotetext{
*Autor para correspondência

${ }^{1}$ Recebido para publicação em 16/11/2012; aprovado em 14/10/2013

Pesquisa realizada na Universidade Federal do Ceará como parte da dissertação da primeira autora

${ }^{2}$ Programa de Pós-Graduação em Agronomia/Fitotecnia, Universidade Federal do Ceará, Caixa Postal 12.1 68, Campus do Pici, Fortaleza-CE, Brasil, 60.356-001, dennisedecastro@gmail.com

${ }^{3}$ Departamento de Fitotecnia, Universidade Federal do Ceará/UFC, Fortaleza-CE, Brazil, alekdurtra@ufc.br

${ }^{4}$ Universidade Federal do Ceará, Caixa Postal 12.168 Campus do Pici, Fortaleza-CE, Brasil, 60.356-001, julianamcamilo17@gmail.com
} 


\section{INTRODUCTION}

Sesame (Sesamum indicum L.) belongs to the pedaliácea family and is probably the oldest oilseed plant used by man. Sesame presents ample adaptability to various conditions of climate and soil, resistance to drought and ease of cultivation; characteristics that make it an excellent option for agricultural diversification and of great economic potential in the domestic and international markets (BARROS et al., 2001). The main product of the sesame plant are its seeds which are rich in mineral components such as calcium, phosphorus, potassium, iron, magnesium, selenium and zinc (EMPRESA BRASILEIRA DE PESQUISA AGROPECUÁRIA, 2012a ). The oil extracted from the seeds is characterized as being a high-quality edible oil with a high content of unsaturated fatty acids, especially oleic and linoleic acids (EMPRESA BRASILEIRA DE PESQUISA AGROPECUÁRIA, 2012b).

Storage is a basic practice in the control of the physiological quality of the seed and is a method through which the viability of the seeds can be preserved and their vigour kept at a reasonable level during the time between planting and harvesting (AZEVEDO, 2003). The ability of the seeds to maintain their quality during storage is influenced by several factors, including water content when the seeds were stored, the temperature and relative humidity of the air in the storage environment, and the packaging used for preserving the seeds (TOLEDO et al., 2009). The high moisture content of the seeds, together with high temperatures, accelerates the natural degeneration processes of the biological systems in such a way that under these conditions the seeds quickly lose their vigour, and shortly after that their capacity for germination (ALMEIDA et al., 1997). On the other hand, seeds with a low water content, and low temperatures in the storage environment, provide the best conditions for maintaining viability (PONTES et al., 2006). Conditions of high relative humidity can occasion the resumption of metabolic activity in the embryo, while high temperatures cause increased respiration and depletion of accumulated reserve substances (AGUIAR, 1995 apud BORBA FILHO; PEREZ, 2009). For better conservation of orthodox seeds, such as those of the sesame, environments with lower relative humidity and temperatures have proved themselves to be suitable, since these conditions allow for the preservation of the capacity for germination and of seed vigour. The conservation of the physiological quality of the seeds is also related to the type of packaging used, and depends on the greater or lesser facility this offers to the exchange of water vapour between the seeds and the atmosphere of the environment under which they are stored (MARCOS FILHO, 2005).
Maintaining the viability of seeds by storing them under controlled environmental conditions has been one of the most important lines of research in seeds of a great number of species. Given the above, the present work had as its objective to monitor the viability of sesame seeds stored in different environments, in different packaging and for different periods of storage, with a view to maintaining their physiological quality.

\section{MATERIAL AND METHODS}

The present work was developed in the Laboratory of Seed Analysis of the Department of Plant Science at the Federal University of Ceará (UFC) in Fortaleza, Ceará, Brazil, in 2011. Sesame seeds from the cultivar BRS Seda were used in the experiment. The seeds were packed into four types of packaging: paper bags, multiwall paper, black polyethylene and PETE bottles, and kept in the following environments: dry cold room $\left(10{ }^{\circ} \mathrm{C}\right.$ and $\left.55 \% \mathrm{RH}\right)$, natural environment $\left(30-32{ }^{\circ} \mathrm{C}\right.$ and $\left.75 \% \mathrm{RH}\right)$, refrigerator $\left(4{ }^{\circ} \mathrm{C}\right.$ and $\left.38-43 \% \mathrm{RH}\right)$ and freezer $\left(-20{ }^{\circ} \mathrm{C}\right)$ for a period of 12 months. Initially and every three months thereafter, the seeds were evaluated for physiological quality through the following determinations and tests: a) water content: determined using the oven method at $105{ }^{\circ} \mathrm{C} \pm 3{ }^{\circ} \mathrm{C}$ for 24 hours, with four replications of 50 seeds per treatment. The results were expressed as a percentage; b) germination test: 100 seeds were used per treatment, which were randomly distributed into sterile petri dishes $9 \mathrm{~cm}$ in diameter, using as substrate "Germitest" paper moistened with distilled water in the ratio of 2.5 times the weight of the dry paper. The dishes and seeds were placed into a BOD germination chamber set to a constant temperature of $25^{\circ} \mathrm{C}$; c) accelerated ageing: Utilizing the procedure described by Marcos Filho (1999), 100 seeds were spread over an aluminum screen fixed into a plastic gerbox containing $40 \mathrm{~mL}$ of distilled water. The boxes with the seeds were closed and kept at $41{ }^{\circ} \mathrm{C}$ for 48 hours, when the seeds were subjected to a germination test, the percentage of normal seedlings being evaluated on the third day after sowing; d) speed of emergence index: The test for the speed of emergence index was carried out using 100 seeds per treatment, divided into four replications of 25 seeds. The seeds were sown in beds of $10.0 \times 1.0 \mathrm{~m}$, at a depth of $0.01 \mathrm{~m}$ and in lines spaced $0.15 \mathrm{~m}$ apart. Irrigation was carried out whenever necessary in order to supply water for seed germination and seedling emergence. Daily counts of the emerged seedlings were taken every 24 hours for fourteen days. Those seedlings where the cotyledons had emerged through the surface of the sand were counted. The speed of emergence index was calculated according to the formula proposed by Maguire (1962). 
The work was carried out in a completely randomised experimental design, in a scheme of split lots, with four replications. Data were subjected to regression analysis. For the factor storage period, polynomial regression analysis was performed, employing the SISVAR software.

\section{RESULTS AND DISCUSSION}

Analyzing the data shown in Figure 1, it can be seen that all the seeds showed variations in water content, independent of the environment and the type of packaging used for storage. In the natural environment and freezer, the seeds packed in paper showed a high percentage of moisture in the third month of storage, reaching 10.5 and $12.5 \%$ respectively. According to Marcos Filho (2005) the water content of the seeds is a direct function of the relative humidity of the air with which they are in close contact, and where they undergo a permanent exchange of water. In the dry cold room, the greatest percentages of moisture were observed in the third month of storage for those seeds packed in multiwall paper and black polyethylene. Bezerra et al. (2004), when evaluating the physiological quality of moringa seeds during storage, found that for seeds stored in a natural environment, the water content

Figure 1 - Water content $(\%)$ of sesame seeds stored in different environments and packaging during 12 months of storage

Natural environment

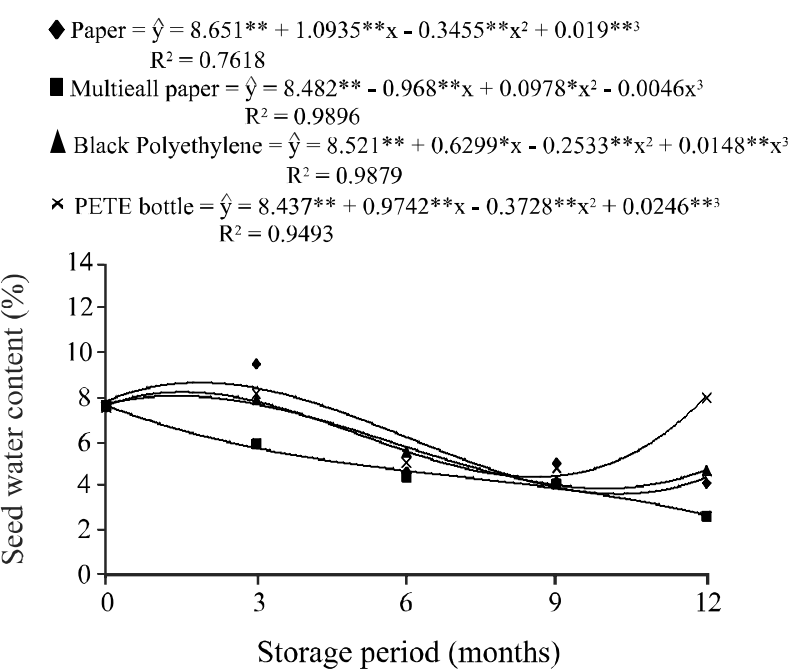

Refrigerator

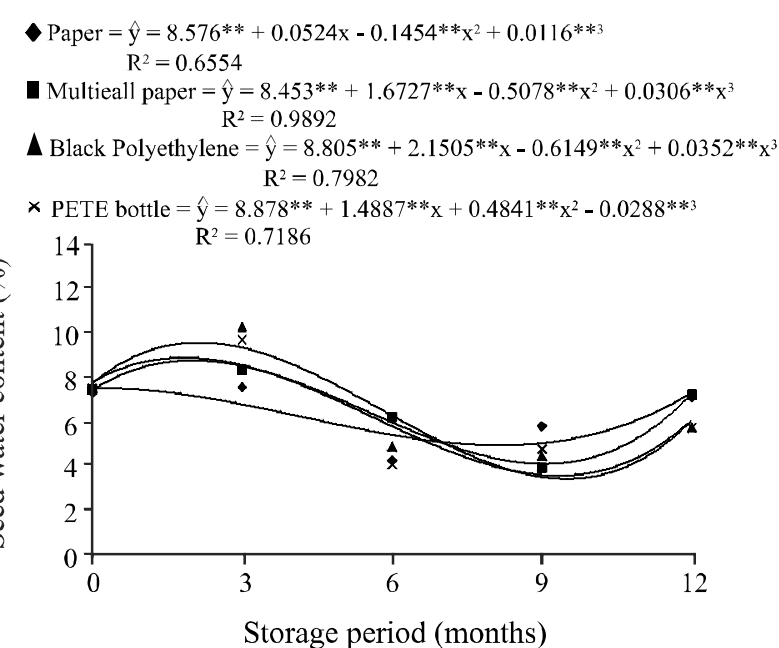

Dry cold room

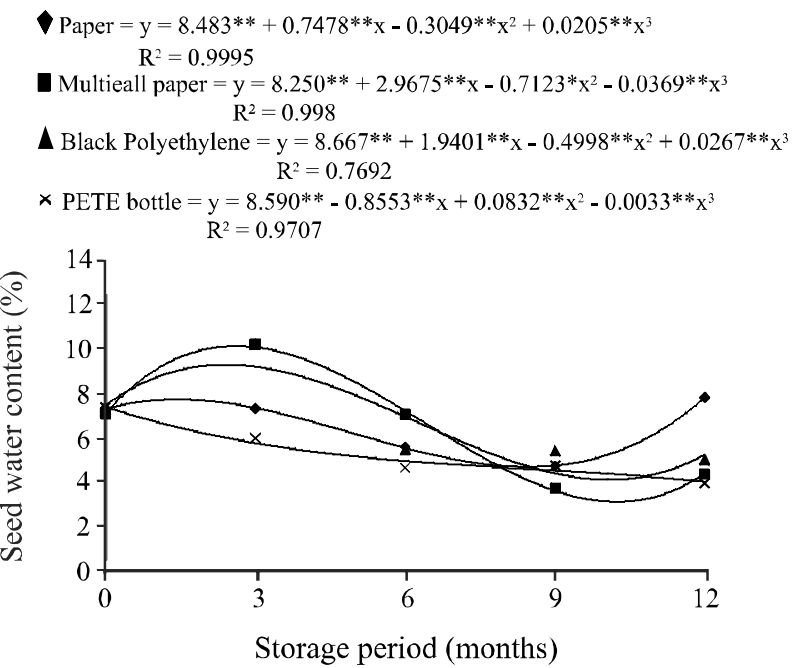

Freezer

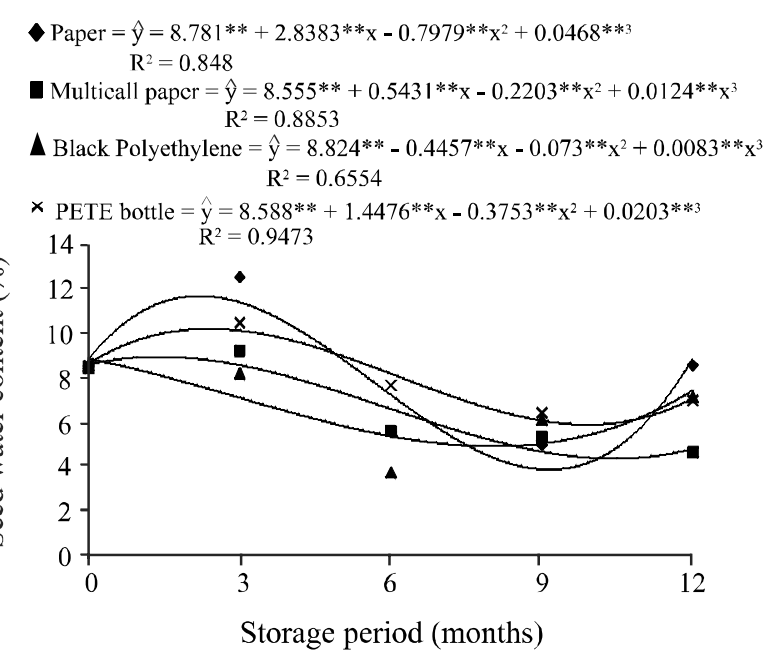


decreased slowly as the storage period progressed, while for those in a cold room, the variation in water content was greater. In a refrigerated environment, the largest fluctuations in water content were observed during the third month of storage in those seeds stored in black polyethylene bags and PETE bottles. The increase in the water content of seeds kept in waterproof packaging is due to the higher respiratory rate of the seeds stored in that type of packaging, which provides a greater release of water and an increase in the relative humidity inside the packaging, the seeds thus seek to adjust to the new relative humidity of the air, and consequently aquire a water content higher than the initial level (CARVALHO; NAKAGAWA, 2009). Catunda et al. (2003) stated that the refrigerator maintains a temperature of $4{ }^{\circ} \mathrm{C}$, but is limited, due to having a high relative humidity which results in an increase in the moisture content of the seeds.

The seeds stored in a natural environment presented the greatest reductions in germination. Within this environment, the seeds stored in paper and multiwall-paper packaging remained viable until the ninth month of storage, when from then on, a significant reduction in germination was seen (Figure 2). This low percentage of germination presented by the seeds may be related to their low water content. According to Carvalho and Nakagawa (2000), under very low levels of water content the rate of deterioration would increase, due to the fact that the macromolecules that make up the reserve substances would be directly

Figure 2 - Germination (\%) of sesame seeds stored in different environments and packaging during 12 months of storage

Natural environment

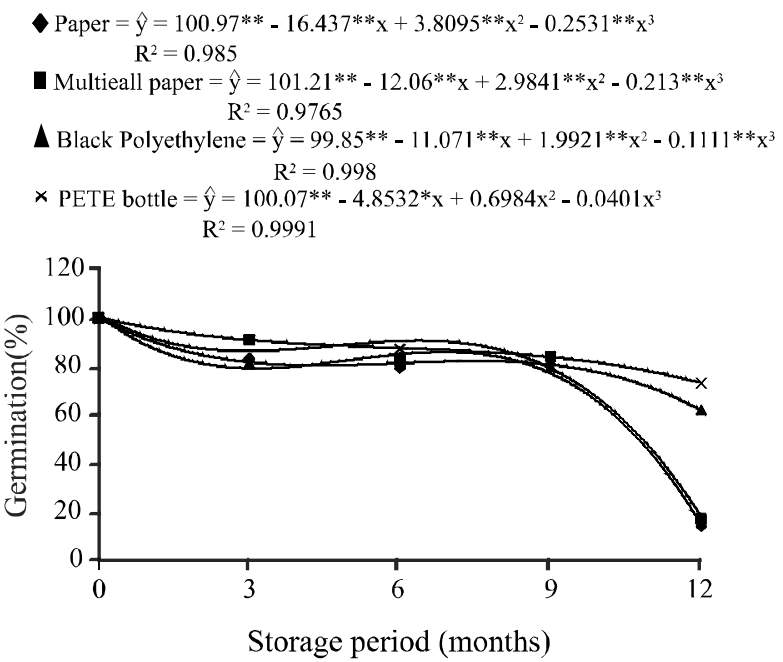

Refrigerator

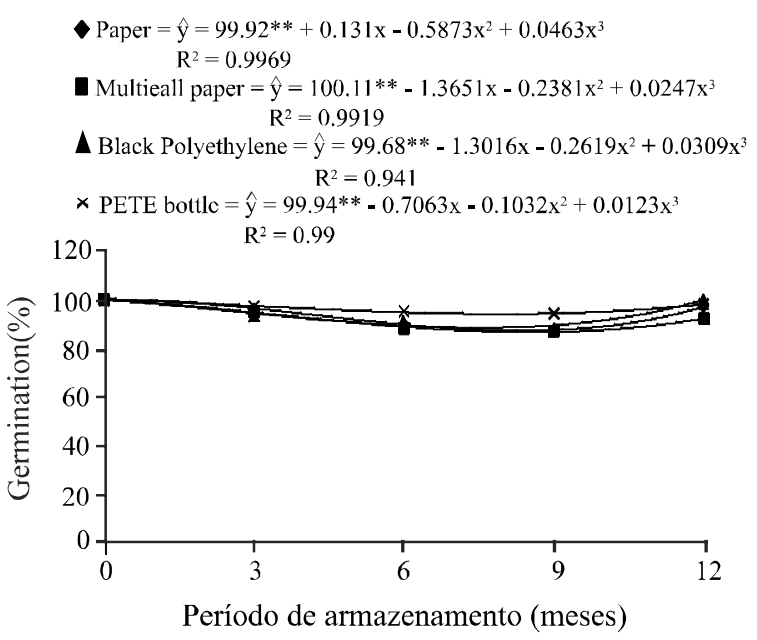

\section{Dry cold room}

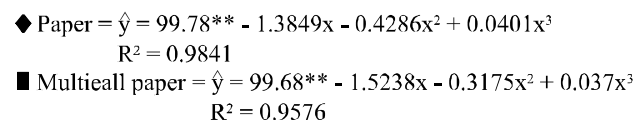

$\Delta$ Black Polyethylene $=\hat{y}=99.82 * *-2.5079 x+0.1349 x^{2}+0.0062 x^{3}$ $\mathrm{R}^{2}=0.9711$

$\times$ PETE bottle $=\hat{y}=99.57^{* *}+2.7302 x-0.9683 x^{2}+0.0617 x^{3}$ $\mathrm{R}^{2}=0.8505$

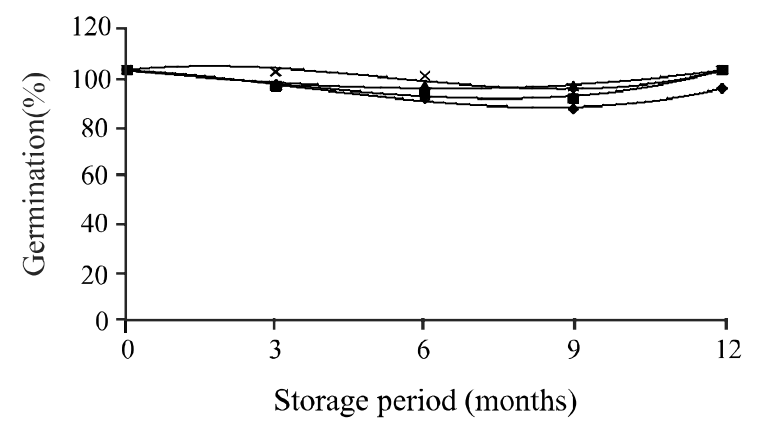

Freezer

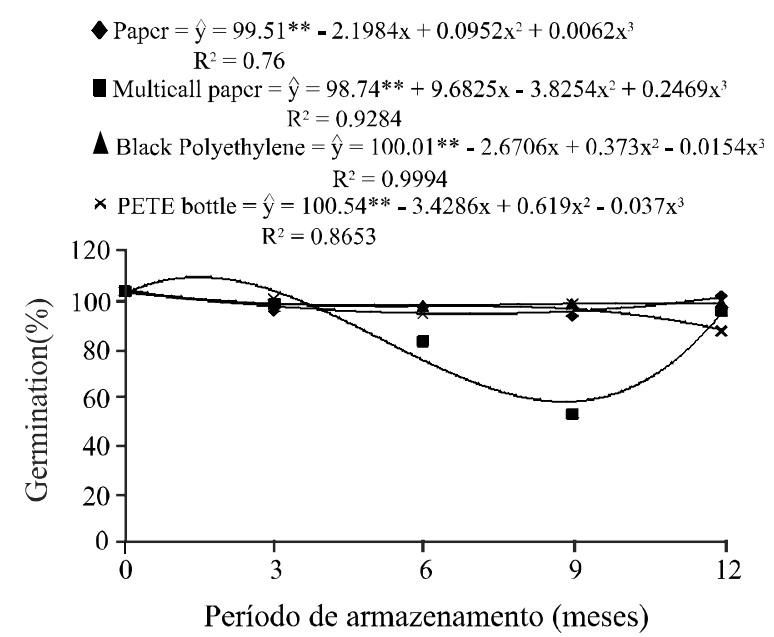


exposed to the oxygen in the air, resulting in oxidation reactions and thus the deterioration of these substances. Whereas those seeds that were stored in a cold room or refrigerator showed germination percentages of over $80 \%$ throughout the storage period. This suggests that the low temperature decreased the respiratory activity of the seeds, contributing to their conservation. Chaves et al. (2012) concluded that storage in refrigerated and cooled environments reduces the physiological quality of Jatropha seeds to a lesser extent. Souza et al. (2007), when evaluating conservation in oilseeds of the mastic tree (Myracroduon urundeuva) under different storage conditions, observed that the most favourable conditions for the germination of this species occurred in the cold room, conserving seed germination for 180 days. In the freezer, seeds packed in multiwall paper presented a marked decrease in the ninth month of storage (Figure 2). Storage at temperatures below freezing may lead to the formation of ice crystals within the cells (SANTOS, 2000), causing damage to the seeds and affecting their ability to germinate.

Analysing Figure 3 it can be seen that seeds stored in a natural environment were considered less vigorous than seeds stored in the controlled environments (cold room, refrigerator and freezer) using the first-count germination test. Temperature has considerable control over the preservation of the quality of stored seeds as it influences biological activities, accelerating the respiratory process of the seeds and microorganisms associated with them. Low temperature environments

Figure 3 - First count for germination (\%) of sesame seeds stored in different environments and packaging during 12 months of storage

Natural environment
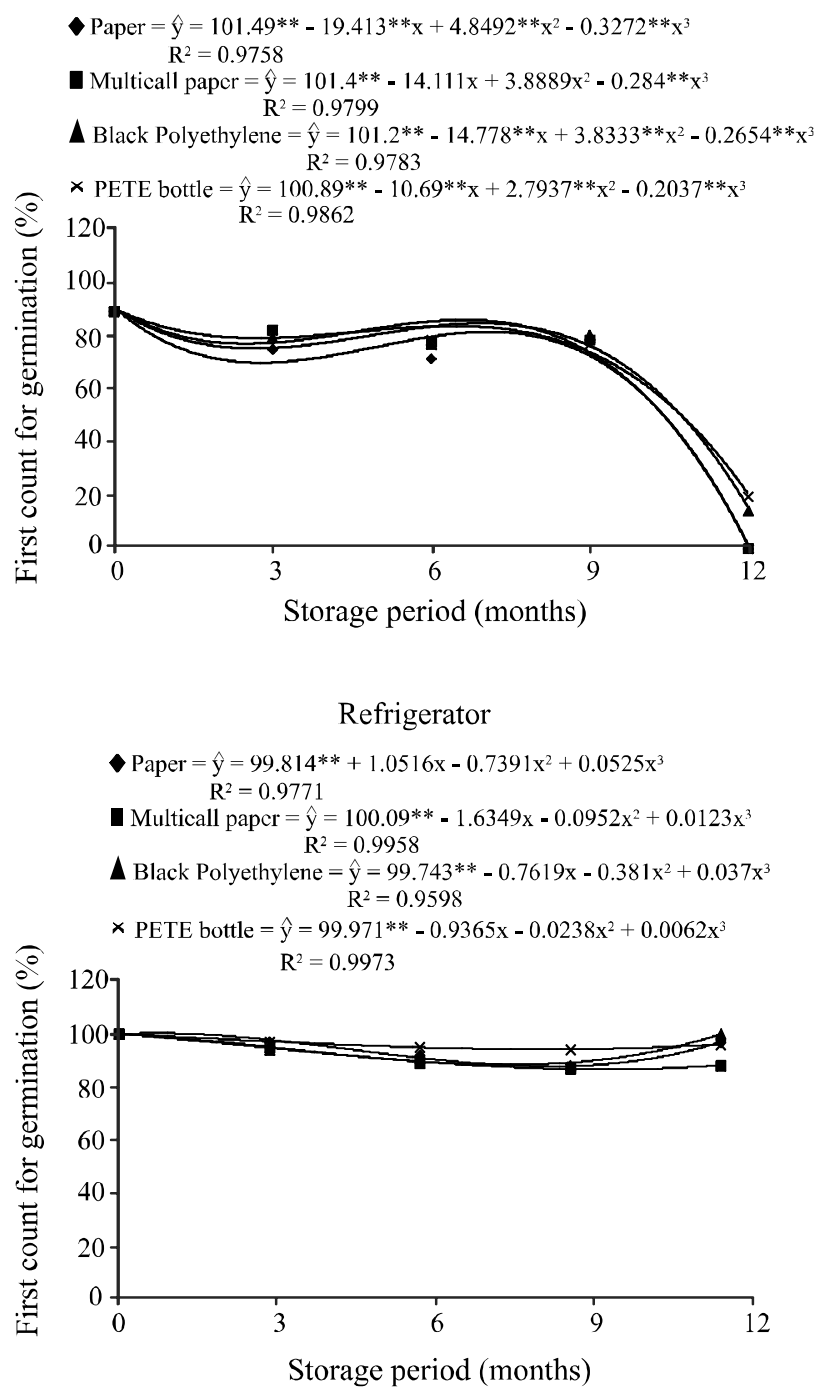

Dry cold room

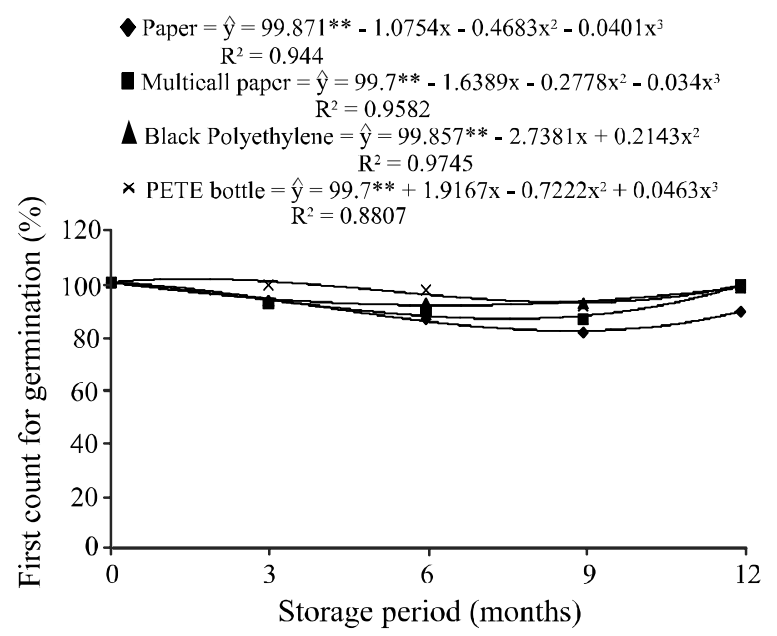

Freezer

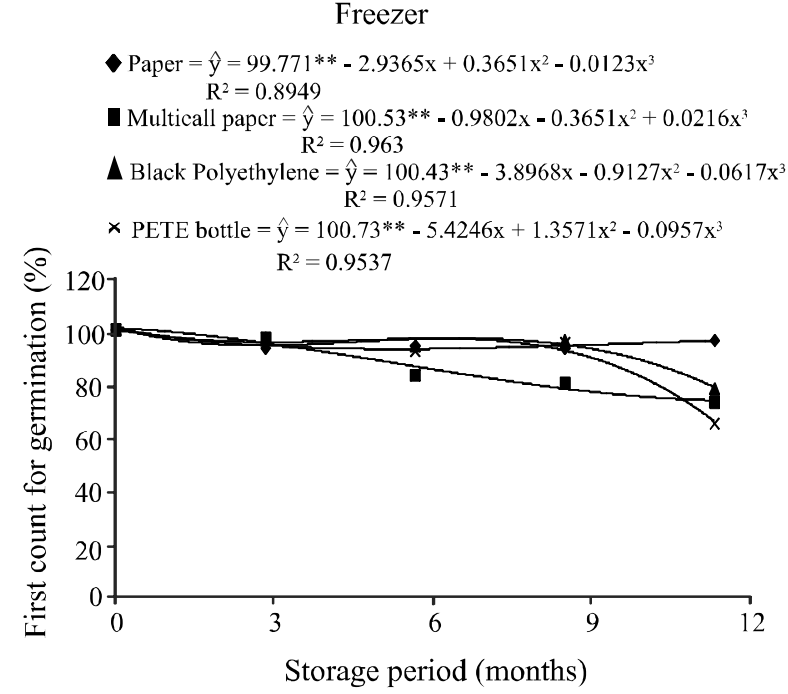


are the most suitable for the conservation of seeds of this species providing smaller reductions in vigour when compared to a natural environment. In the natural environment, the seeds placed into paper and multiwall-paper packaging showed the lowest percentage of normal seedlings at the first count for germination, with a total loss of vigour in the twelfth month of storage (Figure 3). Caldeira and Perez (2008) found that diaspores kept in a room environment rapidly lost their initial viability and vigour after six months of storage. In the freezer, seeds kept in PETE bottles showed a reduction in vigour in the twelfth month, i.e. at temperatures of $-20^{\circ} \mathrm{C}$ seed metabolism still occurs and the viability of the seeds may be reduced (STANWOOD, BASS, 1981 apud MARQUES, 2007).
Seed vigour, evaluated through accelerated ageing, showed that those seeds stored in a natural environment or stored in paper and multiwall-paper packaging showed the greatest reductions in vigour during storage, reaching $12 \%$ and $11 \%$ vigour respectively in the twelfth month of storage (Figure 4). Teófilo et al. (2004) observed the physiological quality of oilseeds of the mastic tree when stored in different environments and packaging for 12 months, using the accelerated ageing test, and found that those seeds stored in multiwall-paper bags and kept in a natural environment were less vigorous than those stored in other packaging. The cold room and refrigerator environments were the most suitable for storage of the seeds, with more seed vigour being maintained throughout the storage period. In the freezer environment, seeds kept in multiwall-paper packaging or in PETE bottles

Figure 4 - Accelerated ageing (\%) of sesame seeds stored in different environments and packaging during 12 months of storage
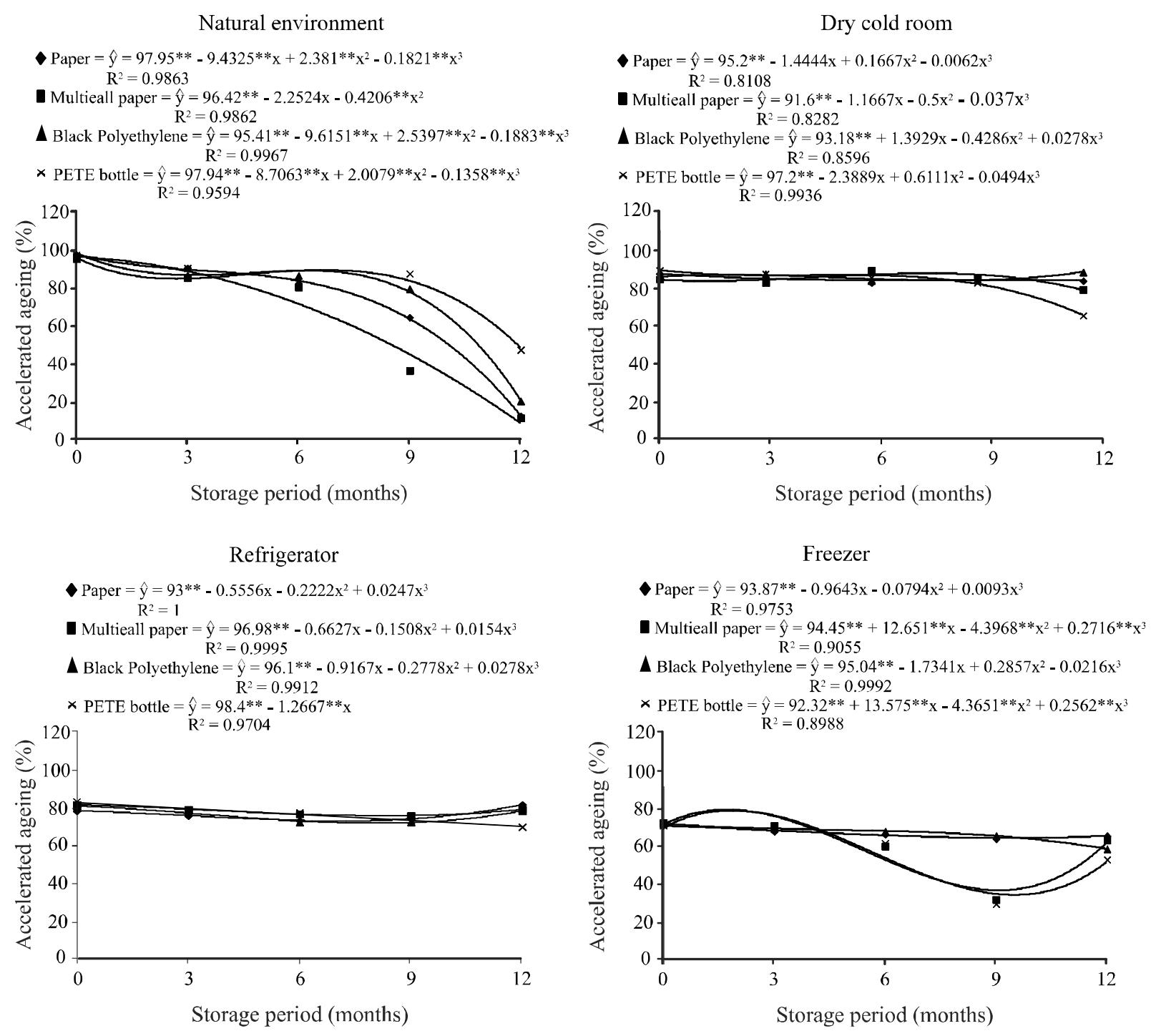
underwent a reduction in vigour in the ninth month of storage (Figure 4). Small seeds absorb water more quickly and less uniformly during the ageing period, which may accelerate the deterioration process or result in variations in behaviour between seeds of a single sample interfering with the accuracy of the results (BHERING et al. 2006). Abreu et al. (2011) observed that the stress condition imposed by the accelerated ageing test greatly reduced the number of normal sunflower seedlings after nine months of storage.

From Figure 5 it can be seen that regardless of the packaging and storage environment, there was a drop in the speed of emergence index of the seeds in the first three months; in the sixth month this index starts to increase again, in the ninth month a sharp drop in these values is seen, and in the twelfth month this index increases in such a way as to present the highest values for the speed of emergence index (SEI). Since this test was carried out in beds, under natural environmental conditions, the seeds were exposed to adverse factors (temperature, humidity, rainfall, etc) which at certain times of the year may have been favourable or unfavourable to the development of the seedlings. Seeds from the PETE bottles in the natural environment or the refrigerator showed the highest values of SEI, 3.03 and 5.08 respectively (Figure 5). Azeredo et al. (2005) observed a sharper reduction in vigour in seeds stored in foil packaging (waterproof) under the conditions of an uncontrolled environment, using the speed of emergence index. In the cold room, seeds kept in black polyethylene showed the greatest SEI (6.00) at the end of the storage period. In the freezer, seeds kept in paper packaging showed the highest values for SEI (5.79) in the twelfth month of storage (Figure 5).

Figure 5 - Speed of emergence index of sesame seeds stored in different environments and packaging during 12 months of storage

Natural environment

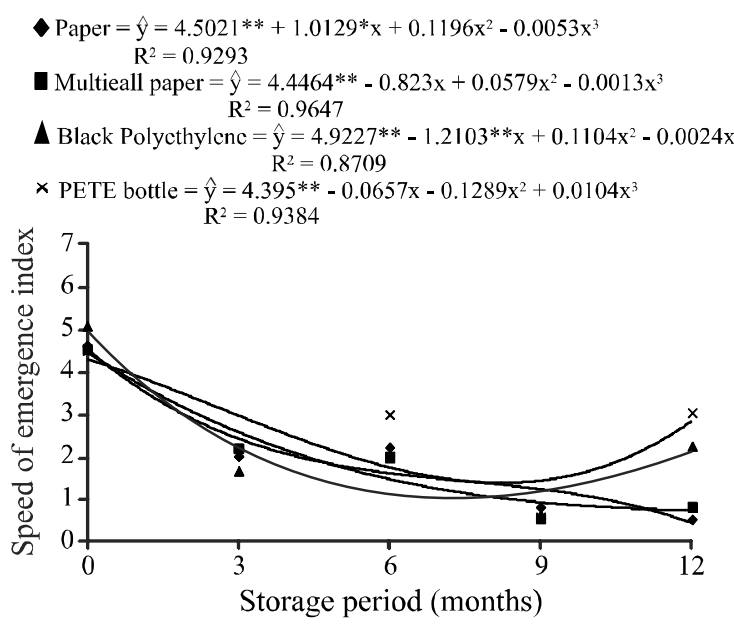

Refrigerator

$\begin{aligned} & \text { Paper }= \hat{y}=4.6399^{* *}-0.4825 \mathrm{x}-0.0397 \mathrm{x}^{2}+0.0058 \mathrm{x}^{3} \\ & \mathrm{R}^{2}=0.8057\end{aligned}$

Multieall paper $=\hat{y}=4.6368^{* *}-0.6027 \mathrm{x}-0.0341 \mathrm{x}^{2}-0.0068 \mathrm{x}^{3}$ $\mathrm{R}^{2}=0.7628$

$\Delta$ Black Polyethylene $=\hat{y}=4.3044 * *-0.195 x+0.0896 x^{2}+0.0085 x^{3}$ $\mathrm{R}^{2}=0.6513$

$\times$ PETE bottle $=\underset{y}{\hat{y}}=4.7368^{* *}-0.2652 x-0.1238 x^{2}+0.0123^{* *} x^{3}$
$R^{2}=0.8594$

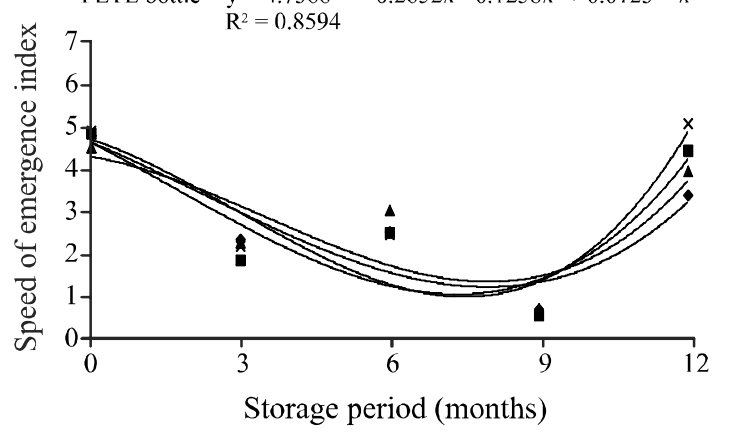

Dry cold room
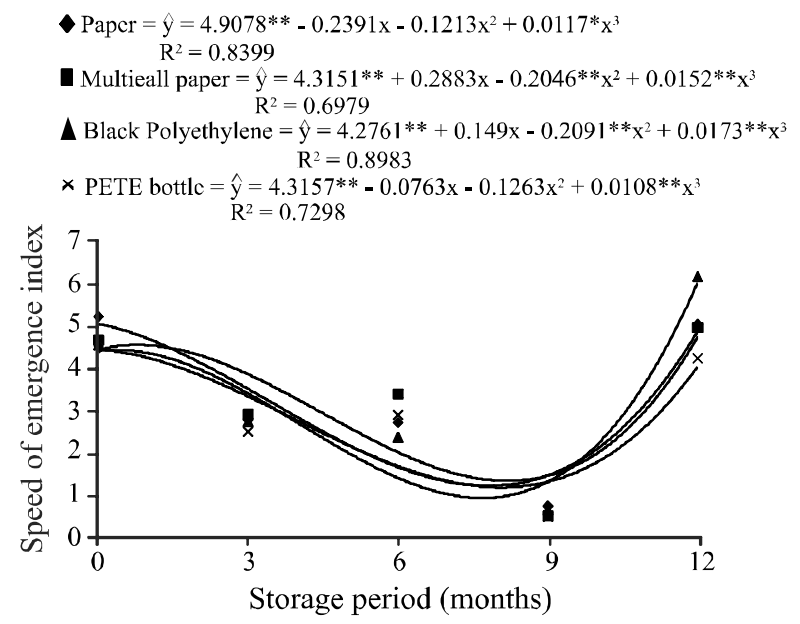

Freezer

$\diamond$ Papcr $=\hat{y}=4.4622 * *-0.3694 x-0.0833 x^{2}+0.0101 * * x^{3}$ $\mathrm{R}^{2}=0.7927$ $\begin{aligned} \text { Multicall paper }= & \hat{y}=4.3845^{* *}-0.2176 \mathrm{x}-0.1224 \mathrm{x}^{2}+0.0118^{* *} \mathrm{x}^{3} \\ & \mathrm{R}^{2}=0.8509\end{aligned}$

$\Delta$ Black Polyethylene $=\hat{y}=4.4401 * *+0.0989 x+0.1688^{*} \mathrm{x}^{2}+0.0134^{* *} \mathrm{x}^{3}$ $\mathrm{R}^{2}=0.6513$

$\begin{aligned} \times \text { PETE bottle }= & \hat{y}=4.5869 * *-0.2916 x-0.221 * * x^{2}-0.0167 * * x^{3} \\ & R^{2}=0.8283\end{aligned}$

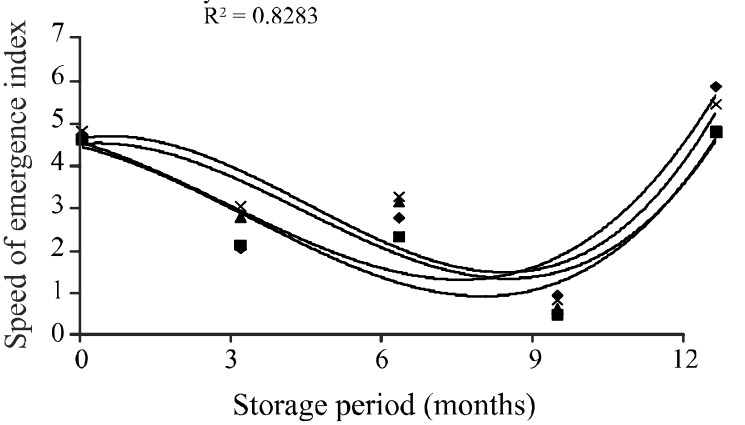




\section{CONCLUSIONS}

1. Seeds remain viable for up to 12 months when stored in a dry cold room or refrigerator environment, regardless of the type of packaging used;

2. In the natural environment the seeds remain viable for up to six months;

3. In a freezer environment, paper packaging was the most suitable for storing sesame seeds for a period of 12 months.

\section{REFERENCES}

ABREU, A. S. et al. Teste de condutividade elétrica na avaliação de sementes de girassol armazenadas sob diferentes temperaturas. Revista Brasileira de Sementes, v. 33, n. 4, p. 635-642, 2011.

ALMEIDA, F. de A. C. et al. Armazenamento de sementes nas propriedades rurais. Campina Grande: UFPB. 1997. 291 p.

AZEREDO, G. A. et al. Conservação de sementes de amendoim (Arachis hypogae L.) em função do beneficiamento, embalagem e ambiente de armazenamento. Pesquisa Agropecuária Tropical, v. 35, n. 1, p. 37-44, 2005.

AZEVEDO, M. R. Q. A. et al. Influência das embalagens e condições de armazenamento no vigor de sementes de gergelim. Revista Brasileira de Engenharia Agrícola e Ambiental, v. 7, n. 3, p. 519-524, 2003.

BARROS, M. A. et al. Importância econômica e social. In: BELTRÃO, N. E. de M; VIEIRA, D. J. O. Agronegócio do gergelim no Brasil. Campina Grande: Embrapa Algodão; Brasília: Embrapa Informação Tecnológica, 2001. 348 p.

BEZERRA, A. M. E. et al. Avaliação da qualidade das sementes de Moringa oleifera Lam. Durante o armazenamento. Ciência e Agrotecnologia, v. 28, n. 6, p. 1240-1246, 2004.

BHERING, M. C. et al. Teste de envelhecimento acelerado em sementes de pimenta. Revista Brasileira de Sementes, v. 28, n. 3, p. 64-71, 2006.

BORBA FILHO, A. B.; PEREZ, S. C. J. G. de A. Armazenamento de sementes de ipê-branco e ipê-roxo em diferentes embalagens e ambientes. Revista Brasileira de Sementes, v. 31, n. 1, p. 259-269, 2009.

CARVALHO, N. M.; NAKAGAWA, J. Sementes: ciência, tecnologia e produção. Jaboticabal: FUNEP, 2009. 588 p.

CHAVES, T. H. et al. Qualidade das sementes de pinhão manso durante o armazenamento em três ambientes. Revista Semina, v. 33, n. 5, p. 1653-1662, 2012.
CALDEIRA, S. F.; PEREZ, S. C. J. G. A. Qualidade de diásporos de Myracrodruon urundeuva Fr. All. armazenados sob diferentes condições. Revista Brasileira de Sementes, v. 30, n. 3, p. 185-94, 2008.

CATUNDA, P. H. A. et al. Influência do teor de água, da embalagem e das condições de armazenamento na qualidade de sementes de maracujá amarelo. Revista Brasileira de Sementes, v. 25, n. 1, p. 65-71, 2003.

EMPRESA BRASILEIRA DE PESQUISA AGROPECUÁRIA. CultivodoGergelim: composição química e usos. Disponívelem: <http://sistemasdeproducao.cnptia.embrapa.br /FontesHTML/ Gergelim/CultivodoGergelim/composicaoquimica.html>. Acesso em: 05 nov. 2012a.

EMPRESA BRASILEIRA DE PESQUISA AGROPECUÁRIA. Cultivo do Gergelim: apresentação. Disponível em: <http:// sistemasdeproducao.cnptia.embrapa.br/FontesHTML/Gergelim/ CultivodoGergelim/index.html>. Acesso em: 05 nov. 2012b.

MAGUIRE, J. D. Speed of germination-aid in selection and evaluation for seedlig emergence and vigor. Crop Science, v. 2, n. 2, p. 176-177, 1962.

MARCOS FILHO, J. Fisiologia de sementes de plantas cultivadas. Piracicaba: FEALQ, 2005. 495 p.

MARCOS-FILHO, J. Teste de envelhecimento acelerado. In: KRZYZANOWSKI, F. C.; VIEIRA, R. D.; FRANÇA NETO, J. B. (Ed.). Vigor de sementes: conceitos e testes. Londrina: ABRATES, 1999. cap. 3, p. 1-24.

PONTES, C. A. etal. Influência da temperatura de armazenamento na qualidade das sementes de Caesalpinia peltophoroides Benth. (sibipiruna). Revista Árvore, v. 30, n. 1, p. 43-48, 2006.

QUEIROGA, V. P. et al. Qualidade fisiológica e composição química das sementes de gergelim com distintas cores. Revista Agro@mbiente, v. 4, n. 1, p. 27-33, 2010.

SANTOS, I. R. I. Criopreservação: potencial e perspectivas para a conservação de germoplasma vegetal. Revista Brasileira de Fisiologia Vegetal, v. 12, p. 70-84, 2000. Número Especial.

SOUZA, S. de C. A. et al. Conservação de sementes de Myracroduon urundeuva Freire Alemão (Anacardiaceae) em diferentes condições de armazenamento. Revista Brasileira de Biociências, v. 5, p. 1140-1142, 2007. Suplemento 2.

TEÓFILO, E. M. et al. Qualidade fisiológica de sementes de aroeira (myracrondrun urundeuva ALLEMÃO) em função do tipo de embalagem, ambiente e tempo de armazenamento. Revista de Ciência Agronômica, v. 35, n. 2, p. 371-376, 2004.

TOLEDO, M. Z. et al. Qualidade fisiológica e armazenamento de sementes de feijão em função da aplicação tardia de nitrogênio em cobertura. Pesquisa Agropecuária Tropical, v. 39 , n. 2 , p. $124-133,2009$ 